NASA Technical Memorandum 100139

AIAA-87-9053

\title{
Recent Developments in Indium Phosphide Space Solar Cell Research
}

\author{
(NASA-TU-100159) BECEAT DEVEICEMENTS IN \\ N\& $7-26141$ \\ IACIUE EHCSPHIDE SFACE SCLAF CELI BESEABCH \\ (NASA) $13 \mathrm{p}$ Avail: NIS EC AO2, HE AO1 \\ CSCI 10B Unclas \\ G3/20 0085264
}

David J. Brinker and Irving Weinberg

Lewis Research Center

Cleveland, Ohio

Prepared for the

22nd Intersociety Energy Conversion Engineering Conference

cosponsored by the AIAA, ANS, ASME, SAE, IEEE, ACS, and AIChE

Philadelphia, Pennsylvania, August 10-14, 1987 


\title{
RF.CENT DEVELOPMENTS IN INDIUM PHOSPHIDE SPACE SOLAR CELL RESEARCH
}

\author{
David J. Brinker and Irving Weinberg \\ National Aeronautics and Space Administration \\ Lewis Research Center \\ Cleveland, Ohio 44135
}

\begin{abstract}
SUMMARY
Recent developments and progress in indium phosphide solar cell research for space application are reviewed. Indium phosphide homojunction cells have been fabricated in both the $n^{+} p$ and $p^{+} n$ configurations with total area efficiencies of 17.9 and 15.9 percent (air mass 0 and $25^{\circ} \mathrm{C}$ ) respectively. Organometallic chemical vapor deposition, liquid phase epitaxy, ion implanta. tion and diffusion techniques have been employed in InP cell fabrication. A theoretical model of a radiation tolerant, high efficiency homojunction cell has been developed. A realistically altainable AMO efriciency of 20.5 percent was calculated using this model with emilter and base doping of $6 \times 10^{17}$ and $5 \times 10^{76} \mathrm{~cm}^{3}$ respectively. Cells of both configurations have been irradi. ated with $1 \mathrm{MeV}$ electrons and $37 \mathrm{MeV}$ protons. For both proton and electron irradiation, the $n^{+} p$ cells are more radiation resistant at higher fluences than the $p^{+} n$ cells. The first flight module of four inP cells has been assembled for the Living Plume Shield II satellite.
\end{abstract}

\section{INTRODUCTION}

Indium Phosphide (InP) homojunction solar cells hold great promise for space power generation because of their inherent radiation resistance and low temperature annealability as well as their potential for high efficiency. A development program, underway since 1984, has the goal of maximizing the end of life efficiency of InP space cells through the optimization of conversion efficiency and radiation tolerance. Advancement toward this goal is being macie through the investigation of a number of fabrication techniques, proton and electron irradiation testing, aircraft flight cell calibration, and the devel opment of a flight module for the Living Plume Shield (LIPS) III satellite. In this paper we report on the recent progress in InP cell development, empha sizing work in the this country and including results from abroad.

\section{STATE-OF-THE-ART IN CELL PERFORMANCE}

Significant progress has been made toward improving the conversion effi. ciency of Inp space solar cells in both the $n^{+} p$ and $p^{+} n$ configurations. Previously reported results (ref. l) of InP AMO efficiencies were restricted to the $n^{+} p$ type. Furthermore, junction formation was limited to the diffusion of sulfur or selenium by either the open tube (ref. 2) or sealed ampoule (ref. 3) method. In the past year, however, high efficiencies have been meas ured in both configurations and cells have been fabricated by liquid phase epi taxy (LPE) and organometallic chemical vapor deposition (OMCVO) of the active layers as well as the diffusion technique. 
The higher minority carrier diffusion length of electrons in $p$-InP (in comparison to the hole diffusion length in $n$-InP) makes the $p$-type material the logical choice for the base of the solar cell. At the same time, the higher electron mobility in $n$-InP can allow a shallower n-type emitter for a given doping level than a $p$-type emitter. For these reasons, the $n^{+} p$ structure appears to be the configuration of choice and, consequently, most investigators have concentrated their efforts in this direction. Table I summarizes the results of AMO measurements of $n^{+} p$ InP cells made by OMCVD, ion implantation and open tube diffusion. The highest AMO total area efficiency achieved to date is 17.9 percent in an $n^{+} \mathrm{pp}^{+}$cell made by the OMCVD junction formation technique (ref. 4). The cell was formed by the growth of three epilayers on a $\mathrm{Zn}$-doped InP substrate ( $\mathrm{fig}$. 1). The $\mathrm{p}^{+}$layer $\left(5 \times 10^{18} \mathrm{Zn} / \mathrm{cm}^{3}\right)$ is $0.5 \mu \mathrm{m}$ thick and serves as a buffer. The active base region is $3 \mu \mathrm{m}$ thick and $\mathrm{Zn}$ - doped to $2 \times 10^{16} \mathrm{~cm}^{-3}$. The emitter layer as grown is about $0.1 \mathrm{\mu m}$ thick and is doped with $s i$ to a level of about $10^{18} \mathrm{~cm}^{-3}$. Formation of the cell entirely in epitaxially grown material may eliminate performance degradation due to residual defects in the substrate caused by the slicing and polishing processes, as evidenced in ion implanted cells. The OMCVO cells had a reduced space charge region (SCR) recombination current, which leads to an increased fill factor. The OMCVO technique also allows precise control of emitter thick ness and the possibility of further enhancement of performance through the use of graded dopant profiles.

Ion implanted junction cells were fabricated by the implantation of ${ }^{28} \mathrm{Si}^{+}$ into an InP substrate $\mathrm{Zn}$-doped to $2 \times 10^{16} \mathrm{~cm}^{-3}$. Emitter thickness was $0.2 \mathrm{~mm}$. The best results were obtained using capless annealing in flowing $\mathrm{PH}_{3}$. The lower fill factor is due to increased SCR recombination and series resist. ance. The increased series resistance results from difficulties in contacting the moderately doped substrates used.

Open tube diffusion of sulfur was also used to fabricate $n^{+} p$ cells. The cell structure is shown in figure 2 and cell performance is summarized in table l. The source of sulfur was a vacuum evaporated film of $\mathrm{Ga}_{2} \mathrm{~S}_{3}$ which was encapsulated with $\mathrm{SiO}_{2}$ to prevent degradation of the InP surface (ref. 5). After deposition of the $\mathrm{SiO}_{2}$ layer in a CVD reactor by the pyrolysis of silane and oxygen, diffusion of the sulfur was carried out at $670^{\circ} \mathrm{C}$ in flowing nitro gen for $25 \mathrm{~min}$. This technique resulted in junction depths of approximately $0.06 \mu \mathrm{m}$ with a carrier concentration of $6 \times 10^{18} \mathrm{~cm}^{-3}$. This technique holds promise as a low cost fabrication method and was used in the fabrication of the InP cells used in the radiation studies and on the LIPS III flight experiment.

$P^{+} N^{+}$InP solar cells have been fabricated using both OMCVO and LPE (ref. 6). A novel feature of these cells (fig. 3) is the incorporation of a heavily doped p. In $0.53 \mathrm{Ga} 0.47$ As contacting layer on the front surface of the cells. The layer is perfectly lattice matched to InP and has allowed for fabrication of contacts an order of magnitude lower in specific contact resist ance than those obtained by directly contacting the InP p-layer. This layer also eliminates the possibility of contact metal spikes shorting the extremely thin emitter. For the LPE cells, the three epitaxial layers were grown succes sively in a conventional horizontal growth system. The OMCVU cells were grown in horizontal atmospheric system using a fast switching run-vent manifold. Performance results are listed in table $I$.

Table II sumnarizes the results of both homojunction InP cells and $110 /$ $p$-InP cells measured under terrestrial conditions. The $n^{+} p p^{+}, p^{+} n(r e f .7)$ and 
$p^{+}$in (ref. 8) cells were made using OMCVD, with the performance measured using active areas. The ITO/p-InP cell was made by the vacuum deposition of indium tin oxide (ITO) (ref. 9). Evidence suggests that the cell is indeed a true $n-p$ homojunction, with the indiffusion of tin from the ITO forming the $n$-type emitter. Its performance was measured using the total area.

InP solar cells on silicon substrates hold the promise for high efficiency and radiation hardness coupled with low cost and light weight. Single crystal InP thin films have been successfully grown on si using the OMCvo technique (refs. 10 and 11). The major obstacles encountered in this approach are the high density of dislocations in the InP layer due to the large lattice mismatch and the development of cracks due to the difference in coefficients of thermal expansion. The first reported results of solar cells efficiencies in InP on Si are about 3 percent (AM1.5)(ref. 11). Reduction of the InP film defect density is necessary before efficiencies approaching those achieved in conventional cells are achieved.

\section{THEORETICAL STUDIES}

To ensure continued advances in cell performance in terms of both efficiency and radiation hardness and a better understanding of the mechanisms leading to InP radiation tolerance, a one-dimensional model of the InP shallow homojunction was developed (ref. 12). The goal of the study was to determine the maximum realistically attainable AMO efficiency and the design parameters which would yield this performance. The model is a low-injection, closed-form solution model which includes such considerations as: position- and wavelength dependent optical generation in the emitter, base, space-charge and substrate regions; metal contact area and front SRV; series resistance dependence on grid geometry; and doping dependent mobilities and diffusivities. The effect of $1 \mathrm{MeV}$ electron irradiation was factored into the model by decreasing the indirect lifetimes in the emitter and base and the minority mobility in the base. End-of-life was chosen arbitrarily to be an electron irradiation fluence of $1.0 \times 10^{15} \mathrm{~cm}^{-2}$.

The design parameters for a near-optimum $n^{\prime} p p^{+}$InP homojunction cell are shown in table III. The key features of the design are the very shallow emitter, doped to mid $10^{77} \mathrm{~cm}^{-3}$ range, the presence of a heavily doped back surface field/buffer layer and a front surface recombination velocity of less than $1 \times 10^{5} \mathrm{~cm} / \mathrm{s}$. The total area, AMO, $25^{\circ} \mathrm{C}$ performance of this design is shown in table IV. The maximum achievable efficiency is about 20.5 percent with roughly 10 percent degradation after a fluence of $1 \times 10^{15} 1 \mathrm{MeV} \mathrm{e}^{-} / \mathrm{cm}^{2}$. This performance level is based on the optical and electronic materials parameters available in a low defect density, epitaxially grown InP cell utilizing a buffer layer grown on a good quality substrate. The results of this model are in fair agreement with predictions based on Loferski's calculations of efficiency as a function of bandgap (ref. 13). It also indicated that, al.though impressive results have been achieved in the past year, there is still room for realistic improvement in InP space solar cells performance.

\section{RADIATION LFFECTS}

The effect of radiation on performance for $n^{+} p$ and $p^{+} n$ In $p$ solar cells was determined (ref. 14). The $n^{+} p$ cells were made by the open tube diffusion 
method described earlier, while the $p^{+} n$ cells were fabricated using OMCVD. Preirradiation performance data is given in table $V$. The cells were irradiated with $1 \mathrm{MeV}$ electrons in the Naval Research Laboratories Van de Graaf generator. Solar cell measurements were carried out at NASA Lewis Research Center, using an AMO xenon arc simulator. Performance data is based on total area, including that covered by the front contacts. The $n^{+} p$ cells exhibit greater radiation resistance, as seen in the normalized efficiency plot (fig. 4). The behavior of the remaining parameters at constant high fluence is summarized in table VI.

The change in fill factor, after irradiation, is relatively small and approximately the same for both configurations. Hence relative small changes in shunt and series resistances are not significant factors in comparing the two configurations. Similarly, the percentage change in $v_{O C}$ is approximately the same for both cell types. However, the percentage loss in I $\mathrm{sC}$ is slightly, but definitely, larger for the $p^{+} n$ cell. For further investigation of the loss in $\mathrm{I}_{s c}$ we examined the normalized spectral response shown in figures 5 and 6 . In the figures, $\left(I_{S C}(\lambda)\right)_{\phi}$ is short circuit current at wave. length $\lambda$ and $1 \mathrm{MeV}$ electron fluence $\phi$, while $\left(\mathrm{I}_{S C}(\lambda)\right)_{0}$ is short circuit current in the unirradiated cell at the same wavelength. The position of the p-n junction is computed from the optical path length $1 / \alpha(\lambda)$ where $\alpha(\lambda)$ is the absorption coefficient at wavelength $\lambda$ (ref. 15). From the figures is it seen that most of the current loss occurs in the emitter of the $p^{+} n$ cell and in the base of the $n^{+} p$ cell. From previous results, it has been demonstrated that for $n^{+} p$ In $p$ cells, radiation resistance increases as $p$-dopant concentration increases ( $r e f .16)$. Since the zinc p-dopant concentration in the $p^{+} n$ cell is at least an order of magnitude greater than that present in the $n^{+} p$ cell and since most of the damage occurs in the p-regions of both cells, one would a priori expect comparatively less radiation resistance in the $n^{+} p$ cell. Since this is not the case for the present cells, the current results are considered to be anomalous. In any event, it is concluded that the relatively decreased radiation resistance of the $p^{+n}$ cell is due to comparatively greater losses in the heavily doped emitter region.

InP cells were also irradiated using $37 \mathrm{MeV}$ protons to a total fluence of $2.6 \times 10^{12} \mathrm{~cm}^{2}$. The $n^{t} p$ cells were, as in the electron study, made by the open tube diffusion technique. The $p^{+} n$ cells were fabricated using OMCVD. At the same time high efficiency GaAs cells of both configurations were irradiated. The results are shown in figure 7. As in the electron case, the $n^{+} p$ configuration is more radiation tolerant than the $p^{+} n$ cells. As is also seen in electron radiation studies, InP is more radiation tolerant than GaAs.

\section{LIPS III FLIGHT EXPERIMENT}

The decision of the Naval Research Laboratory to fly the third Living Plume Shield (LIPS III) satellite in 1987 has provided the first opportunity to obtain flight data, including radiation exposure, of InP solar cells. We have assembled a module of four $n^{+} p$ InP homojunction cells on a $5 \mathrm{~cm}^{2}$ aluminum substrate. The InP solar cells were made by the open tube diffusion technique described earlier. Fifteen cells were obtained for the flight experiment with the best efficiency of the lot the 14.3 percent described in table 1 .

A silver plated Kovar interconnect was soldered to the back of each cell. Front contact consists of six $1.0 \mathrm{mil}$ gold wires ultrasonically bonded to the front contact pad and a gold-plated Kovar bus tab. The design was simple, yet 
rugged enough to survive all preflight testing. The cells were glassed using 12 mil CMX coverglass and the module was assembled using standard silicone space qualified adhesives and Kapton insulation. Each cell was independently wired using a four wire connection, thus allowing for redundancy in case of the failure of any single cell as well as the performance measurement of any single cell. A thin film platinum resistance temperature detector was mounted under a fifth, nonoperative cell located in the center of the module.

The AMO total area efficiencies of the four flight cells ranged from 11.9 to 12.3 percent before assembly into the module. After assembly, they decreased about one percentage point, ranging from 10.9 to 11.5 percent. This drop can be attributed to light attenuation through the coverglass and adhesive and the effect of the interconnect welding and soldering procedures.

\section{SUMMARY OF RESULTS}

Significant gains in efficiency for InP space cells has been made in both the $n^{+} p$ and $p^{+} n$ configurations with 17.9 and 15.9 percent, respectively, the best to date. Cells have been made with a variety of techniques amenable to mass production, including OMCVD, LPE and diffusion. Theoretical studies indicate that 20.5 percent is possible with realistic materials properties and cell design. The superiority of InP over GaAs when subjected to 1 MeV electron and 10 and $37 \mathrm{MeV}$ proton fluences has been demonstrated by radiation testing. A flight module of four $n^{+} p$ cells has been prepared for the LIPS III experiment and will yield the first flight data for InP.

In conclusion, the development of InP solar cells for space application is continuing at a rapid pace. There appears to be no major impediment for further improvements in performance and utilization for space power generation.

\section{REFERENCES}

1. Weinberg, I. and Brinker, D.J., "Indium Phosphide Solar Cells . Status and Prospects for Use in Space," Toward Technology Breakout in Energy Conversion (21st IECEC), Vol. 3, American Chemical Society, Washington, D.C., 1986, pp. 1431-1435. (NASA IM-87315).

2. Parat, K.K., Bothra, S., Borrego, J.M., and Ghandi, S.K., "Solar Cells in Bulk InP Using an Open Tube Diffusion Process," Space Photovoltaic Research and Technology Conference 1986, NASA CP-2475, 1986, pp. 295-300.

3. Yamamoto, A., Yamaguchi, M., and Vemura, C., "High Conversion Efficiency and High Radiation Resistance InP Homojunction Solar Cells," Applied Physics Letters, Vol. 44, No. 6, Mar. 15, 1984, pp. 611-613.

4. Spitzer, M.B., Keavney, C.J., Vernon, S.M., and Haven, V.E., "Junction Formation Techniques for Indium Phosphide Solar Cells, "Proceedings of the 19th Photovoltaic Specialists Conference, IEEE, Piscataway, NJ, 1987, to be published. 
5. Bothra, S., Bhimnathwala, H.G., Parat, K.K., Ghandi, S.K., and Borrego, J.M., "Characterization and Modelling of Open Tube Diffused $n^{+} p$ Bulk Indium Phosphide Solar Cells," Proceedings of the 19th Photovoltaic Specialists Conference, IEEE, Piscataway, NJ, 1987, to be published.

6. Choi, K.Y., Shen, C.C., and Miller, B.I., "P/N InP Homojunction Solar Cells by LPE and MOCVD 1echniques," Proceedings of the 19th Photovoltaic Specialists Conference, IEEE, Piscataway, NJ, 1987, to be published.

7. Sugo, M., Yamamoto, A., and Yamaguchi, M., "n+-p-p+ Structure InP Solar Cells Grown by Organometallic Vapor Phase Epitaxy," IEEE Transactions on Electron Devices, Vo1. 34, No. 4, Apr. 1987, pp. 772-777.

8. Yamaguchi, M., Yamamoto, A., Itoh, Y., and Uemura, C., "22\% Efficient and High Radiation-Resistant InP Solar Cells," Proceedings of the 2nd International Photovoltaic Science and Engineering Conference, Beijing, 1986, pp. 573-576.

9. Coutts, T.J., SERI, private communication.

10. Yamaguchi, M., Yamamoto, A., Uchida, N., and Uemura, C., "A New Approach for Thin-film InP Solar Cells," Solar Cells, Vol. 19, No. 1, 1986, pp. 85-96.

11. Yamaguchi, M., Yamamoto, A., Itoh, Y., and Nishioka, T., "High Efficiency GaAs and InP Thin-Film Solar Cells Fabricated on Si Substrates," Proceedings of the 19 th Photovoltaics Specialists Conference, IEEE, Piscataway, NJ, 1987, to be published.

12. Goradia, C., Geier, J.V., and Weinberg, I., "Modelling and Design of High Efficiency Radiation Tolerant Indium Phosphide Space Solar Cells," Proceedings of the 19th Photovoltaics Specialists Conference. IEEE, Piscataway, NJ, 1987, to be published.

13. Loferski, J., "An Introduction to the Physics of Solar Cells, "Solar Cel1s: Out look for Improved Efficiency. " National Academy of Sciences, Washington, D.C., 1972, pp. 25-49.

14. Weinberg, I., Swartz, C.K., Hart, R.E., and Statler, R.L., "Radiation and Temperature Effects in Gallium Arsenide, Indium Phosphide, and Silicon Solar Cells," Proceedings of the 19th Photovoltaics Specialists Conference, IEEE, Piscataway, NJ, 1987, to be published. (NASA TM-89870).

15. Glembocki, O.J. and Pillar, H., in Handbook of Optical Constants of Solids, E.D. Palik, ed., Academic Press, New York, 1985, pp. 530-516.

16. Yamaguchi, M., Uemura, C., Yamamoto, A., and Shibukawa, A., "Electron Irradiation Damage in Radiation-Resistant InP Solar Cells," Japanese Journal of Applied Physics, Vol. 23, No. 3, Mar. 1984, pp. 302-307. 
TABLE I. - AIR MASS ZERO CELL PARAMETERS OF INP HOMOJUNCTION SOLAR CELLS

\begin{tabular}{|c|c|c|c|c|c|c|}
\hline Cell type & $\begin{array}{c}\text { Growth } \\
\text { technique }\end{array}$ & $\begin{array}{c}\text { Efficiency, } \\
\text { percent }\end{array}$ & $\begin{array}{c}J_{S C,} \\
m A / \mathrm{Cm}^{2}\end{array}$ & $\begin{array}{c}V_{\text {Oc }}, \\
\mathrm{mV}\end{array}$ & $\begin{array}{c}F F, \\
\text { percent }\end{array}$ & Reference \\
\hline$n^{+} p^{+}$ & $\begin{array}{c}\text { OMCVD } \\
n^{+} p\end{array}$ & 17.9 & 33.9 & 868 & 83.7 & 4 \\
$n^{+} p$ & $\begin{array}{c}\text { ion implant. } \\
\text { diffused }\end{array}$ & 14.0 & 31.8 & 801 & 75.3 & 4 \\
\hline$p^{+} n n^{+}$ & OMCVO & 14.3 & 30.6 & 814 & 78.8 & 5 \\
$p^{+} n n^{+}$ & LPE & 15.9 & 32.8 & 864 & 76.7 & 6 \\
\hline
\end{tabular}

aMeasurements performed at NASA Lewis Research Center; total area, $137.2 \mathrm{~mW} / \mathrm{cm}^{2} ; 25^{\circ} \mathrm{C}$.

TABLE II. - InP CELL PARAMETERS AT OTHER THAN AIR MASS ZF.RO

\begin{tabular}{|c|c|c|c|c|c|c|}
\hline Cell type & Air mass & $\begin{array}{c}\text { Efficiency, } \\
\text { percent }\end{array}$ & $\begin{array}{l}3_{s c} \\
m A / c m^{2}\end{array}$ & $\underset{m V}{v_{\text {OC }}}$ & $\begin{array}{c}F F \text {, } \\
\text { percent }\end{array}$ & Reference \\
\hline $\begin{array}{l}n^{+} p p^{+} \\
p^{+} \\
p^{+} \text {in } \\
\text { ITo/p-InP }\end{array}$ & 1.5 & $\begin{array}{l}a_{20.0} \\
a_{18.1} \\
a_{22} 2.0 \\
b_{16.5}\end{array}$ & $\begin{array}{l}30.0 \\
28.2 \\
35.8 \\
27.9\end{array}$ & $\begin{array}{l}830 \\
835 \\
811 \\
790\end{array}$ & $\begin{array}{l}80.0 \\
78.8 \\
76.0 \\
74.8\end{array}$ & $\begin{array}{l}7 \\
8 \\
8 \\
9\end{array}$ \\
\hline
\end{tabular}

active area, $100 \mathrm{mw} / \mathrm{cm}^{2} ; 20{ }^{\circ} \mathrm{C}$.

botal area, $100 \mathrm{mw} / \mathrm{cm}^{2} ; 25{ }^{\circ} \mathrm{C}$.

TABLE III. - DESIGN PARAMEIERS FOR $n^{+} \mathrm{pp}^{+}$InP HOMOJUNCTION SOLAR CFI.L

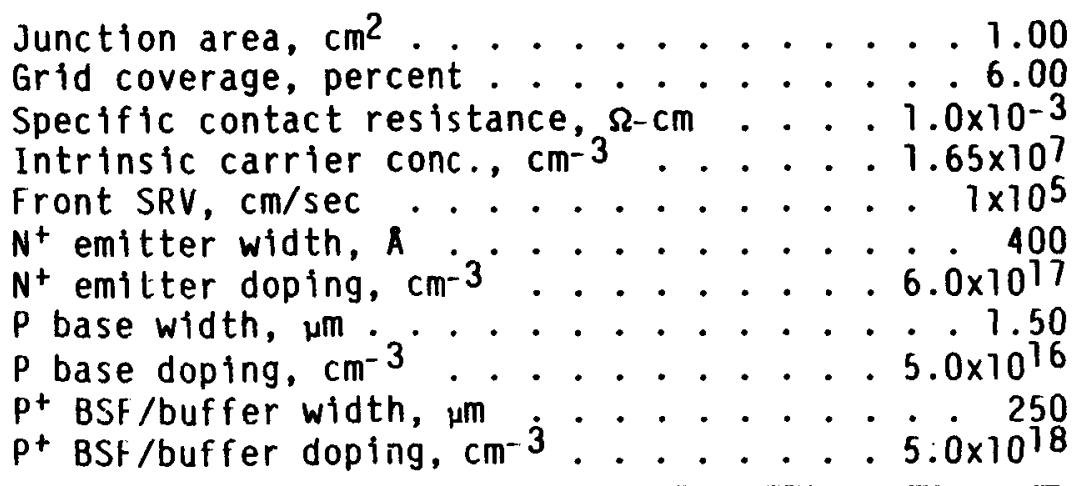


TABLE IV. - THEORETICAL AMO PERFORMANCE OF $n^{+} \mathrm{pp}^{+}$ InP HOMOJUNCTION SOLAR CEI.L

\begin{tabular}{|l|c|c|c|}
\hline & BOL & EOL & EOL/BOL \\
\hline$J_{S c}, \mathrm{~mA} / \mathrm{cm}^{2}$ & 36.53 & 36.09 & 0.988 \\
$\mathrm{~V}_{\mathrm{OC}}, \mathrm{mV}$ & 901.6 & 839.9 & .932 \\
FF, percent & 84.79 & 82.34 & .971 \\
Efficiency, percent & 20.34 & 18.78 & .894 \\
\hline
\end{tabular}

TABLE V. - InP PREIRRADIAT ION PERFORMANCE

PARAMETERS

\begin{tabular}{|c|c|c|c|c|}
\hline Cell & $\begin{array}{c}\text { Efficiency, } \\
\text { percent }\end{array}$ & $v_{\mathrm{OC}}$, & $\begin{array}{l}\mathrm{J}_{\mathrm{sc}} \\
\mathrm{mA} / \mathrm{cm}^{2}\end{array}$ & $\begin{array}{c}F F \text {, } \\
\text { percent }\end{array}$ \\
\hline$n^{+} p$ & $\begin{array}{l}12.9 \\
12.7\end{array}$ & $\begin{array}{r}0.815 \\
.814\end{array}$ & $\begin{array}{l}26.3 \\
26\end{array}$ & $\begin{array}{l}82.6 \\
82.3\end{array}$ \\
\hline$p^{+} n$ & $\begin{array}{l}13.9 \\
14.7\end{array}$ & $\begin{array}{r}0.843 \\
.858\end{array}$ & $\begin{array}{l}32.4 \\
33\end{array}$ & $\begin{array}{l}70 \\
71\end{array}$ \\
\hline
\end{tabular}

TABLE VI. - NORMALIZED INP CELL PARAMEIERS AT CONSIANT HIGH FLUENCE

[InP: $\quad N^{+} p$ and $p^{+} n . \quad d=1$ MeV electron fluence $=3 \times 10^{15} / \mathrm{cm}^{2}$.]

\begin{tabular}{|c|c|c|c|c|c|}
\hline \multicolumn{2}{|c|}{ Cell } & $\varepsilon \phi / \varepsilon_{0}$ & $\left(I_{S C}\right)_{\phi} /\left(I_{S C}\right)_{0}$ & $\left(V_{O C}\right)_{\phi} /\left(V_{O C}\right)_{0}$ & $(F F)_{\phi} /(F F)_{O}$ \\
\hline \multirow{2}{*}{ InP } & $p^{+} n$ & 0.85 & 0.96 & 0.93 & 0.94 \\
& $n^{+} p$ & .82 & .93 & .92 & .95 \\
\hline
\end{tabular}




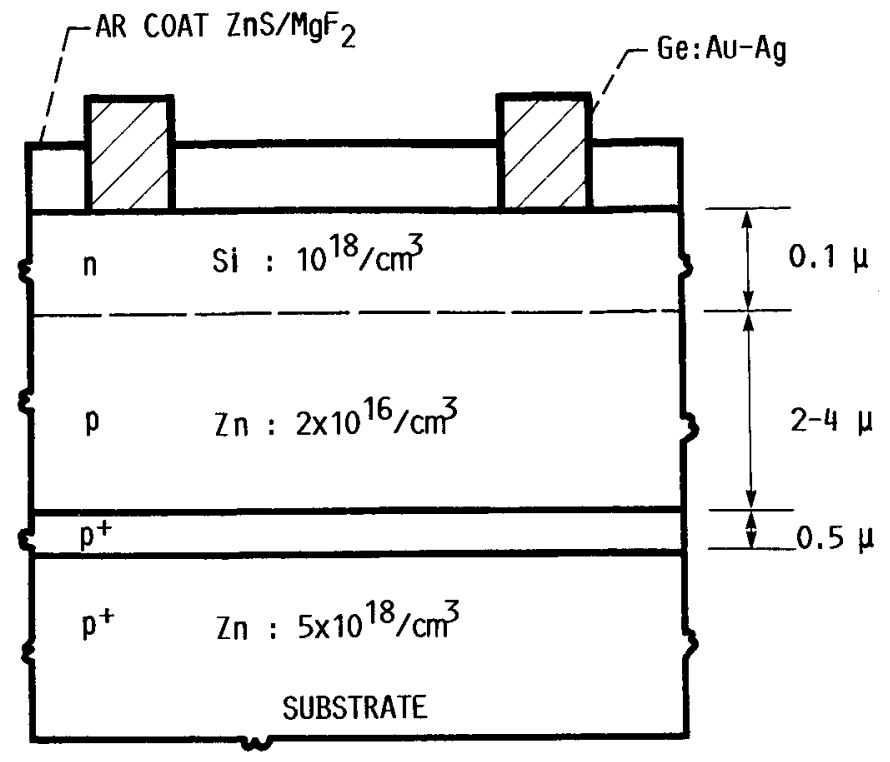

FIGURE 1. $-\mathrm{N}^{+} \mathrm{PP}{ }^{+}$InP CELL STRUCTURE - OMCVD.

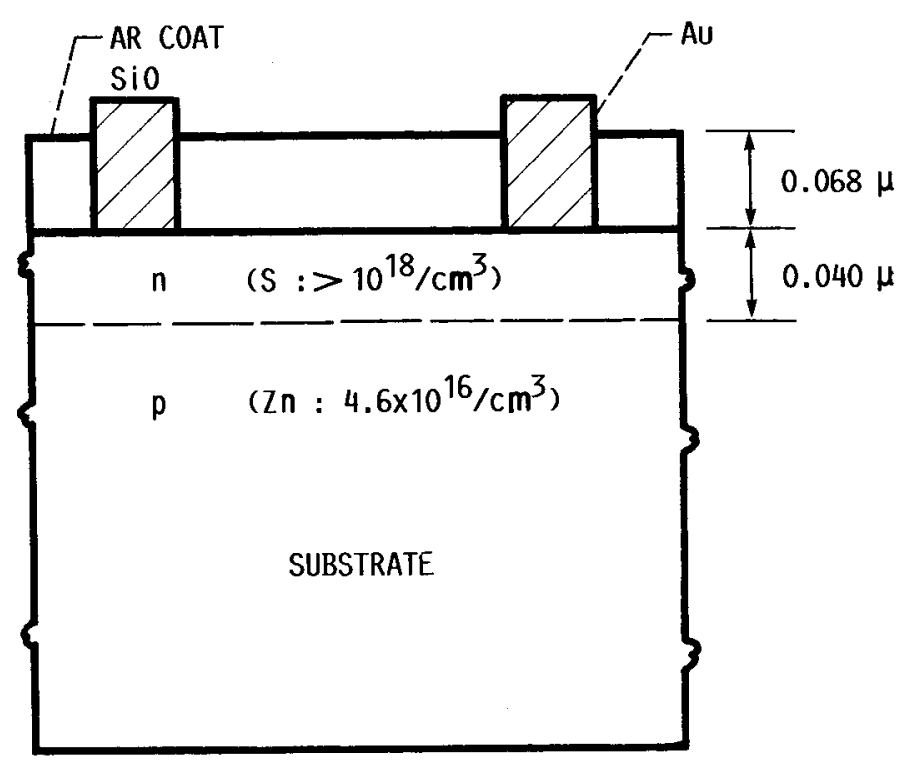

FIGURE 2. $-N^{+}$P InP CELL STRUCTURE - OPEN-TUBE DIFFUSION.

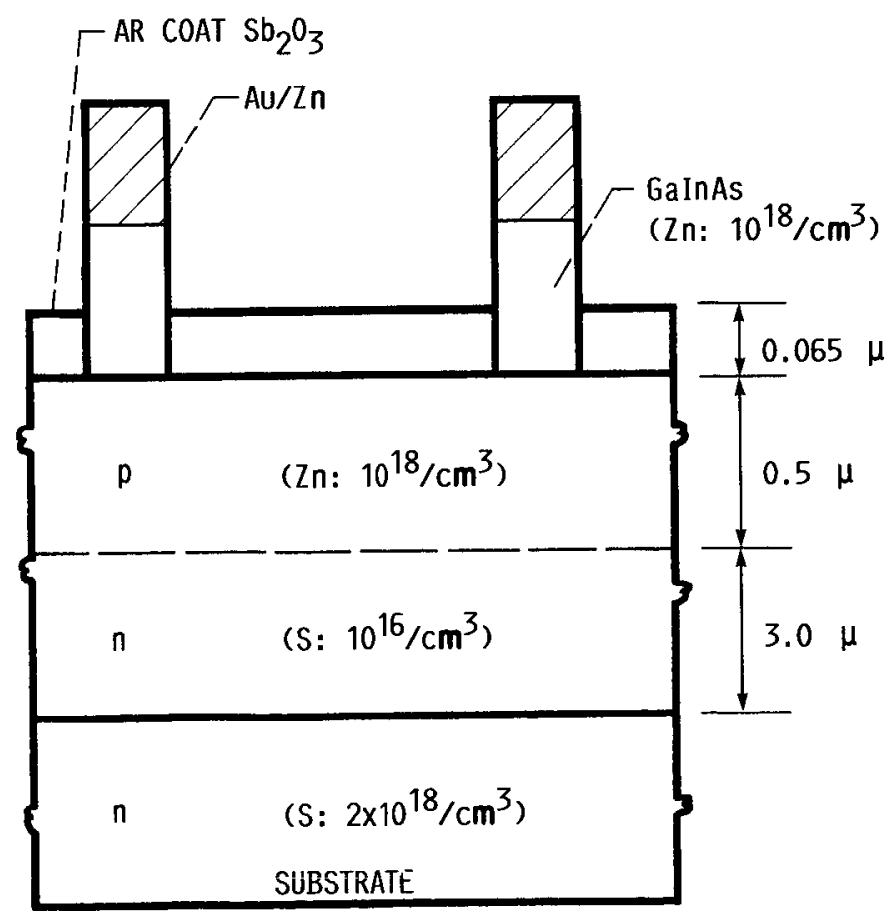

FIGURE 3. $-\mathrm{P}^{+} \mathrm{NN}^{+}$InP CELL STRUCTURE - OMCVD AND LPE. 


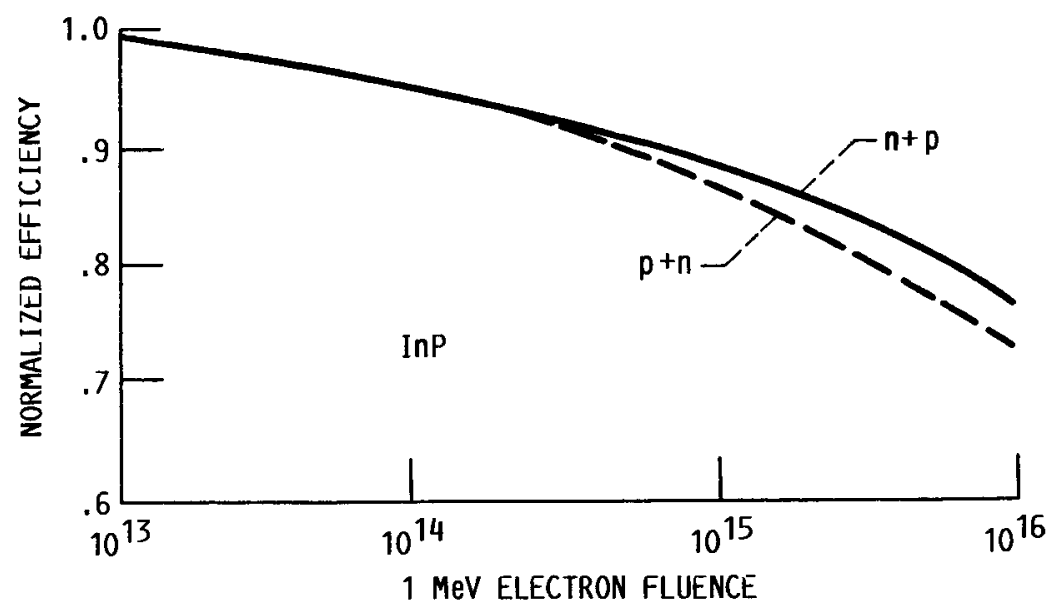

FIGURE 4. - NORMALIZED EFFICIENCY AFTER 1 MeV ELECTRON IRRADIATION.

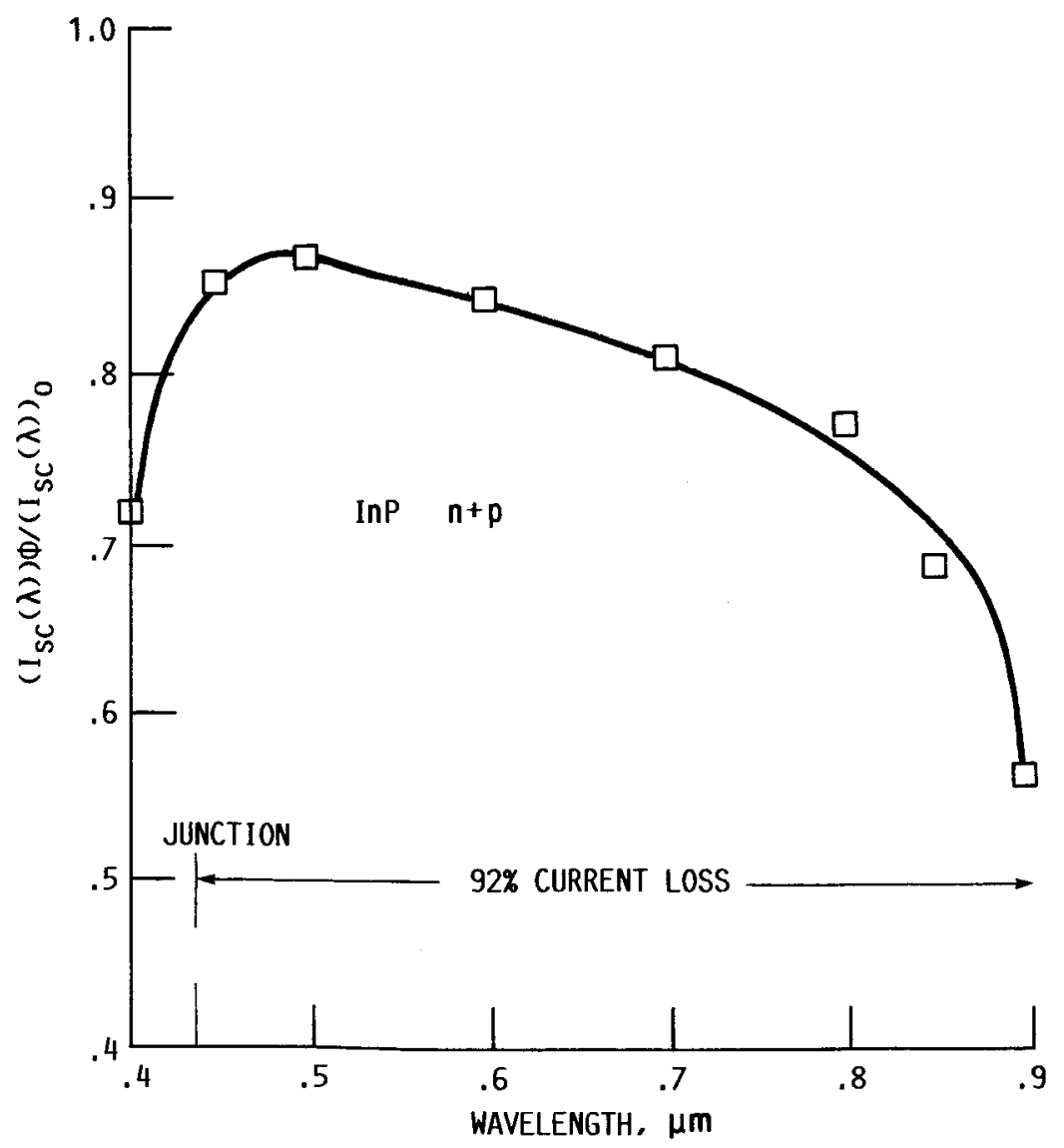

FIGURE 5. - NORMALIZED SPECTRAL RESPONSE OF $n^{+} p$ InP CELL $1 \mathrm{MeV}$ ELECTRON FLUENCE $=3 \times 10^{15} \mathrm{~cm}^{-2}$. 


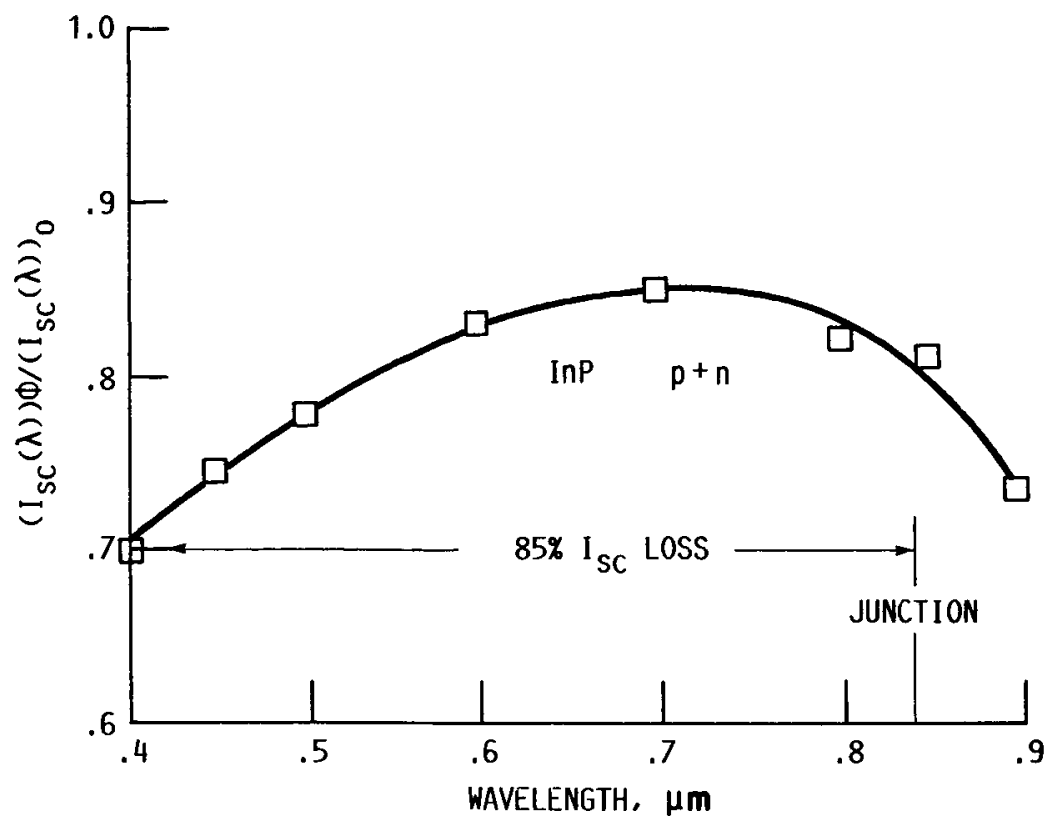

FIGURE 6. - NORMALIZED SPECTRAL RESPONSE OF $n^{+} p$ InP CELL. $1 \mathrm{MeV}$ ELECTRON FLUENCE $=3 \times 10^{15} / \mathrm{cm}^{2}$.

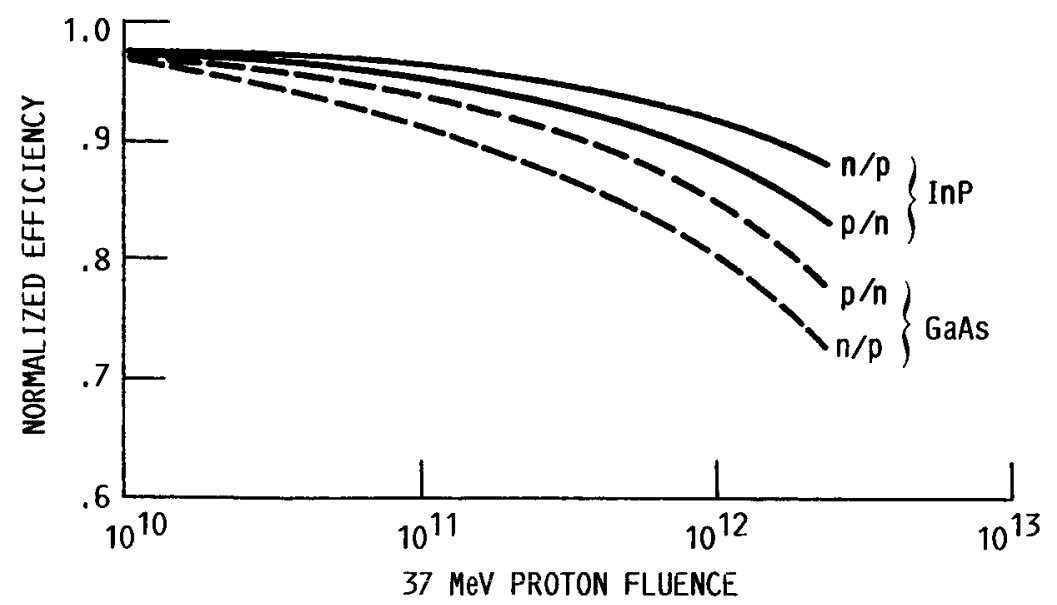

FIGURE 7. - NORMALIZED EFFICIENCY AFTER $37 \mathrm{MeV}$ PROTON IRRADIATION. 


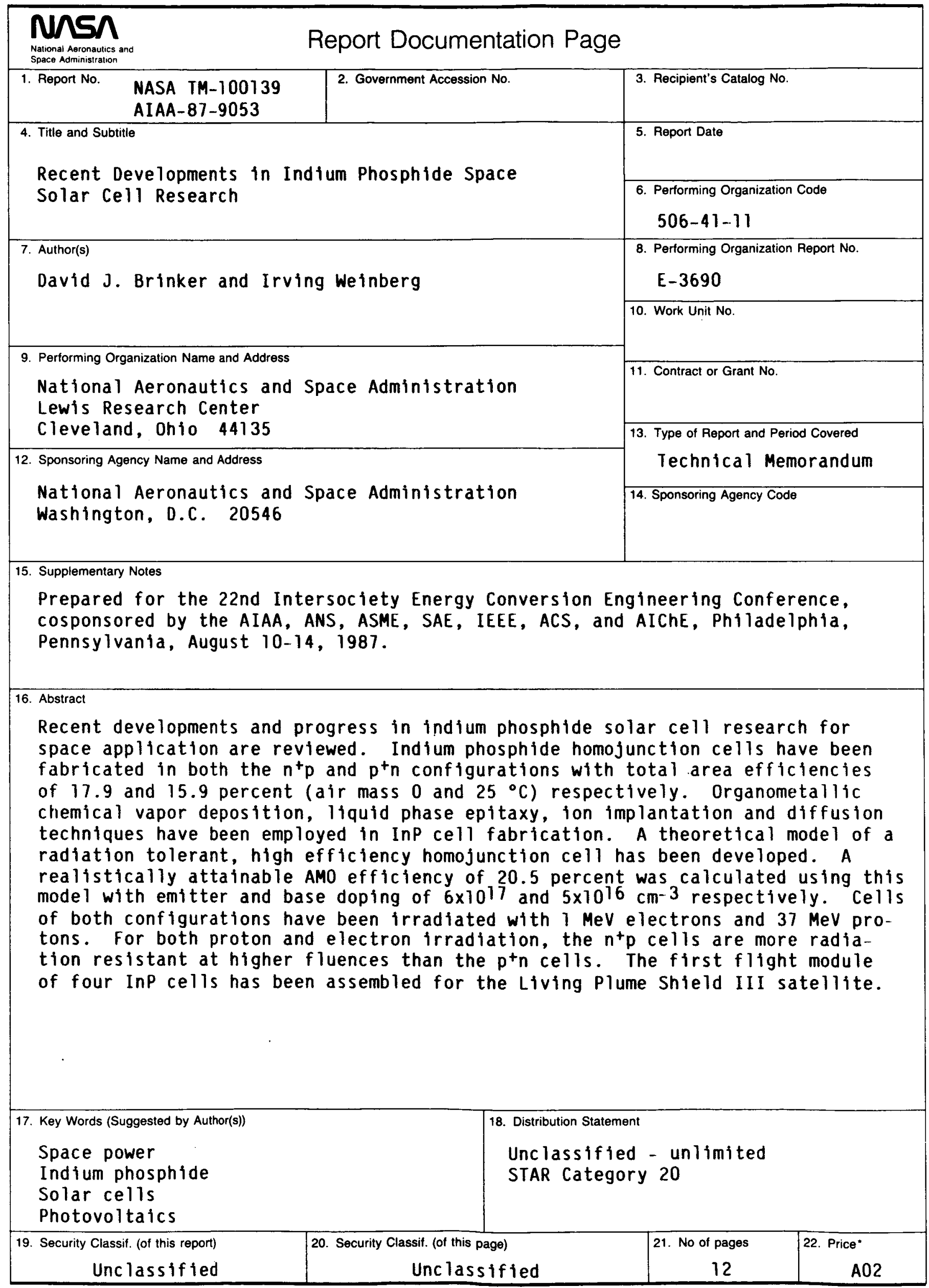

NASA FORM 1626 ocr $86 \quad$ *For sale by the National Technical Information Service, Springfield, Virginia 22161 